\title{
Prenatal development of the lingual epithelium in goat (Capra hircus)
}

\author{
Yousuf Dar*, Kamal Sarma, Shalini Suri and Jonali Devi \\ Division of Veterinary Anatomy, Faculty of Veterinary Sciences, A.H. Sher-e-.Kashmir University of Agricultural \\ Sciences \& Technology, Jammu-181102 (J\&K), INDIA \\ *Corresponding author. E-mail: yousufdar8@gmail.com
}

Received: May 9, 2016; Revised received: December 12, 2016; Accepted: February 10, 2017

\begin{abstract}
The present study was conducted on the tongue of 18 goat foetii divided into three prenatal age groups viz- Group I ( below 50 days of gestation), Group II ( between 50-100 days of gestation) and Group III ( above 100 days of gestation to up to full term) containing 6 number of foetii in each group to study the sequential events in regard to histological development of the same in goat foetii. The tongue was lined by 3-4 layered epithelium in the foetus at 40 days of gestation $(C R L=2.40 \mathrm{~cm})$. The lingual epithelium consisted of a basal layer of cuboidal cells with squamous to cuboidal shaped more superficial layers. At 62 days of gestation (CRL=10.10 cm), the lamina epithelialis of the tongue of goat foetus was distinctly stratified. At this stage of development, the epithelial layers could be divided into dark basal and a light apical or superficial zones. At $80-84$ days of gestation $(\mathrm{CRL}=15.3$ to $16.0 \mathrm{~cm}$ ), the stratified squamous epithelium of the tongue was better developed both on the dorsum and ventral surfaces. At 93 days of gestation $(C R L=20.6 \mathrm{~cm})$, the stratified squamous epithelium of the tongue was well developed and all the layers of the epithelium could be observed. In the foetii of gestational age of 100 days onwards, the lingual epithelium of the tongue showed various degrees of keratinization. Thus, it was concluded that the tongue of goat was lined with 3-4 layers of epithelial cells. The degree of stratification increased with an increase in gestational age. Also with age there was an increase in the degree of keratinization. This research further implicated that with further advancement of age the basal layer of the epithelium comprised high cylindrical cells along with well defined basement membrane. The decrepancy of histogenesis and keratogenesis between different species may be due to difference in the duration of the gestation period.
\end{abstract}

Keywords: Goat, Histomorphology, Prenatal development, Tongue,

\section{INTRODUCTION}

The tongue in mammals is an extremely muscular organ within whose substances there are a number of smaller salivary glands and many number of motor and sensory nerve fibres (Sisson and Grossman, 1975; Dyce et al., 1996). The bulk of tongue is skeletal muscle, arranged in three layers all at right angles to each other (Sisson and Grossman, 1975; Reece, 2004) giving it a degree of flexibility for prehension and mastication of food (Getty, 1975; Dyce et al., 1996). Majority of tongue muscles are somatic in origin (Yamane, 2005). The presence of prominent torus linguae with a crescentic depression - fossa linguae was reported in the tongue of ox and sheep (Habel, 1975), goat (Qayyum and Beg, 1975), buffalo (Dhingra and Barnwal, 1979; Prakash and Rao,1980). The torus linguae probably compensates for the deficient masticatory mechanism caused by absence of incisors in the upper jaw (Labh and Mitra, 1969).

It has been observed that the morphogenesis and cytodifferentiation in developing vertebrate organs is controlled by the sequential and reciprocal interaction between the epithelial and mesenchymal tissues (Jitpukdeebodintra et al., 2002). Development of different papillae occurs prenatally and in a very specific spatial and temporal pattern. Although each type is morphologically distinct, the initial events in the development in all mammals are histologically similar (Mistretta, 1991) and later on there must be progressive differentiation to acquire the papillary epithelial taste progenitor cell and finally taste cell within the papillary apex (Mistretta and Liu, 2006).

In the foetus, the tongue begins to form at approximately the same time as the palates. It extends from various protuberances on the pharynx floor. Already at the time of the medial fusion of the first (mandibular) and second (hyoid) pharyngeal arches a medial protuberance, the tuberculum impar, appears on the lower edge of mandibular arch. To the left and right of it two further swellings form, the lateral lingual prominences. These three swellings extend from the mandibular arch and later form the anterior $2 / 3$ of the tongue. The posterior third is formed from the materials of the fusion site of the second and third pharyngeal archs, the copula, and small portion of $4^{\text {th }}$ pharyngeal arch. The third pharyngeal arch probably grows over the second one so that in the end the second one has no mesenchymal contribution to 
tongue formation. In literature the histogenesis of the tongue has been reported in rat (Farbman, 1965), mouse (Cameron, 1966), buffalo (Verma et al., 2010) and crossbred pig (Sarma et al., 2003) but very scanty literature is available on goats so keeping this in view present investigation was carried out with the objective to study the histogenesis of lingual epithelium in goat.

\section{MATERIALS AND METHODS}

The present study was conducted on the tongue of 18 goat foetii which were collected from the slaughter houses in and around Jammu city. The approximate age ranging from 29 days to 145 days). Immediately after collection, the umbilical cords of these foetii were ligated properly and were cleaned with cotton soaked with water to remove the amniotic fluid. The weight of each foetii was recorded with the help of analytical balance. The approximate age of the foetii were calculated by putting the body weight values in the formula postulated by Singh et al. (1979) for estimation of age in goat foetus. As mentioned below formula for estimation of foetal age in goat (Singh et al., 1979).

$\mathrm{W}^{1 / 3}=0.096(\mathrm{t}-30)$.

Where, $\mathrm{W}=$ body weight of foetus in $\mathrm{gm}$.

$\mathrm{t}=$ age of the foetus in days.

The collected foetii were then divided into three groups based on their estimated ages viz.- Group I ( below 50 days of gestation), Group II (between 50100 days of gestation) and Group III ( above 100 days of gestation to up to full term) containing 6 number of foetii in each group.

After estimation of age, the tongues were dissected out from the foetii. Tissue pieces from the tip, body, torus linguae and root of the tongue were fixed in $10 \%$ Neutral Buffered Formalin solution and processed for paraffin block preparation by alcohol-benzene schedule. Tissue sections of 5-6 mm were obtained from these blocks on clean glass slides with the help of rotary microtome (Luna, 1968). The sections were then subjected to various histological and histochemical methods viz. Haematoxylin \& Eosin, Mallory's Stain, Hart's Stain, Gomori's Stain and Bielschowsky's method for routine histology, collagen fibres, elastic fibres, reticular fibres and nerve fibres, respectively.

\section{RESULTS AND DISCUSSION}

Group I: In the present study, the tongue of goat was lined by 3-4 layered epithelium in the foetus at 40 days of gestation $(\mathrm{CRL}=2.40 \mathrm{~cm})$ (Fig. 1 ) as also observed in 6-7 week human foetus (Bradley and Stern, 1967), in rabbit at $15^{\text {th }}$ day of prenatal life (Kulawik, 2005), in goat fetuses up to $10.0 \mathrm{~cm} \mathrm{CRL} \mathrm{length} \mathrm{(Parmar} \mathrm{et} \mathrm{al.,}$ 1999) and in rats by E12-E14 (Baratz and Farbman, 1975). Igbokwe and Okolic (2009) observed 2-3 layers of cells in lingual epithelium in s50 days old Red Sokoto goat foetii. Again, Verma et al. (2010b) reported that at $2.5 \mathrm{~cm}$ CVR length in buffalo foetus
(40 days of gestation), the tongue was lined by two layers of epithelium: a deep layer of cuboidal cells and a superficial thin sheet of cells and at CVR length 3.4 $\mathrm{cm}$ (44 days of gestation), the dorsal surface of tongue was lined by 3- layered epithelium: a basal layer of cuboidal cells, an intermediate layer and a superficial layer of squamous cells. In the present study also the lingual epithelium consisted of a basal layer of cuboidal cells with squamous to cuboidal shaped more superficial layers.

In the goat foetii at 42 to 49 days of gestation $(\mathrm{CRL}=$ $3.40 \mathrm{~cm}$ to $5.9 \mathrm{~cm}$ ), the lingual epithelium had a well defined basement membrane (Fig.2). Bradley and Stern (1967) and Igbokwe and Okolic (2009) also reported a distinct basement membrane in the lingual epithelium in $6^{\text {th }}-7^{\text {th }}$ weeks human and 50 days old Red Sokoto goat foetus. Underlying the epithelium was the mesenchymal tissue with cells with oval nuclei and scant cytoplasm (Fig. 3)

Group II: At 62 days of gestation $(\mathrm{CRL}=10.10 \mathrm{~cm})$, the lamina epithelialis of the tongue of goat foetii was distinctly stratified. At this stage of development, the epithelial layers could be divided into dark basal and a light apical or superficial zones (Fig.4) as reported earlier in $79^{\text {th }}$ days old buffalo foetus (Uppal et al., 2006) and at 30-35 cm CVR length buffalo foetii (Scala et al., 2005). No sign of keratinisation was observed at this stage. The ventral surface of the tongue was lined by a basal layer of cuboidal cells and a superficial layer of 3-4 layered polygonal shaped cells (Fig.5). The nucleus to cytoplasmic ratio of these cells were very high. Similar observations were also reported by Verma et al. (2010) in buffalo foetus.

With the progress in gestational age, the development of the lingual epithelium continued with the appearance of regularly placed dermal papillae that was formed by sequential evagination and invagination of the lingual epithelium on the dorsum linguae (Fig.6). Such evenly placed dermal papillae was absent on the lingual epithelium on the ventral surface as reported in rat (Farbman, 1971) and Verma et al. (2010) in buffalo foetii. These dermal papillae on the dorsum linguae were separated from each other by 3-4 epithelial cells. The dermal papillae were lined by $2-3$ cell layer thick epithelium as also reported by Baratz and Farbman (1975) in the tongue of rats foetii.

The inter papillary epithelium separating the dermal papillae gradually enhanced in thickness and the dermal papillae continued to grow in length. At this stage, the epithelium of the dorsum linguae of the goat foetus showed numerous growing papillae, majority of them had fungiform appearance (Fig.7), as observed by Sawaf et al. (1991) at $14^{\text {th }}$ week in human tongue and Verma et al. (2010) in tongue of buffalo foetii at 77 days of gestation.

In the present study, at 80-84 days of gestation $(\mathrm{CRL}=15.3$ to $16.0 \mathrm{~cm})$, the stratified squamous 
Yousuf Dar et al. / J. Appl. \& Nat. Sci. 9 (1): 421- 426 (2017)

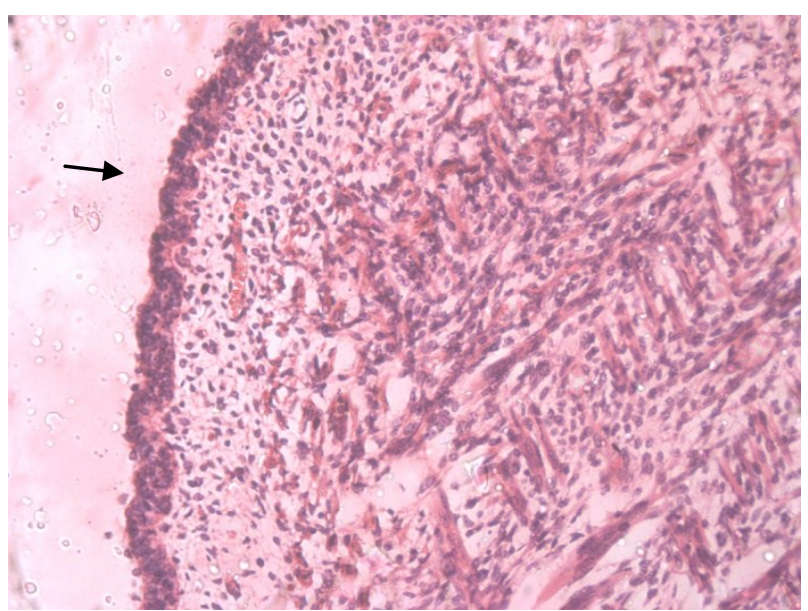

Fig. 1. Photomicrograph showing 3-4 layered thick epithelium (arrow) in the tongue of 40days old goat foetus, $H \& E$, $100 X$.

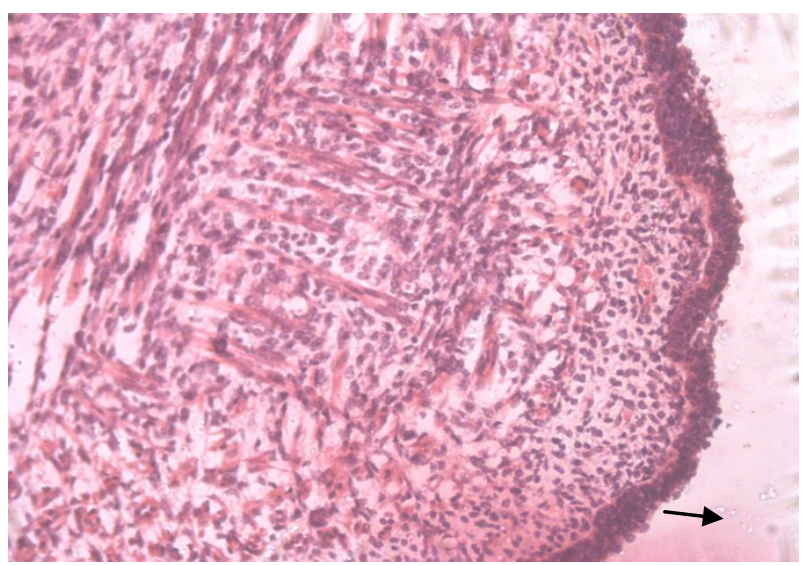

Fig. 3. Photomicrograph showing mesenchymal tissue (arrows) underlying the epithelium with oval nuclei in 49days old foetus, $H \& E, 100 X$.

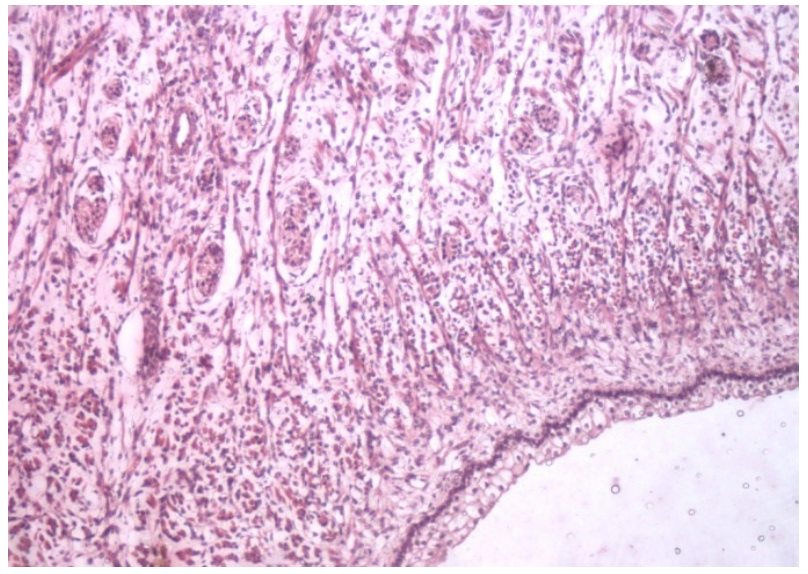

Fig. 5. Photomicrograph of tongue in 62 days old foetus showing ventral surface of tongue lined by a basal layer of cuboidal cells and superficial layer of 3-4 layered polygonal shaped cells, $H \& E, 100 X$.

epithelium of the tongue was better developed both on the dorsum (Fig.8) and ventral surfaces (Fig.9). At 93 days of gestation $(\mathrm{CRL}=20.6 \mathrm{~cm})$, the stratified squa-

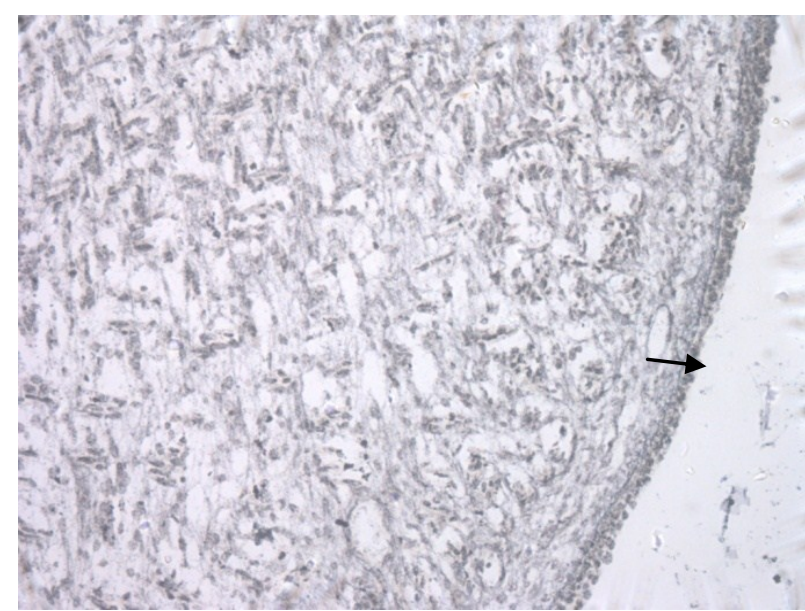

Fig. 2. Photomicrograph showing well defined basement membrane (arrows) in 48 day old goat foetus, Gomori's method, $100 X$

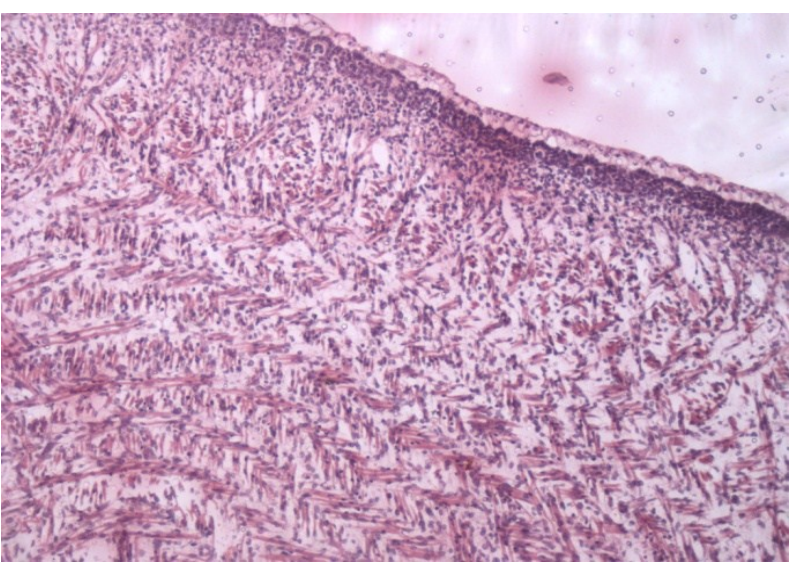

Fig. 4. Photomicrograph showing dark basal (D) and light apical $(L)$ zones of the lingual epithelium in 62 days old foetus, $H \& E, 100 X$.

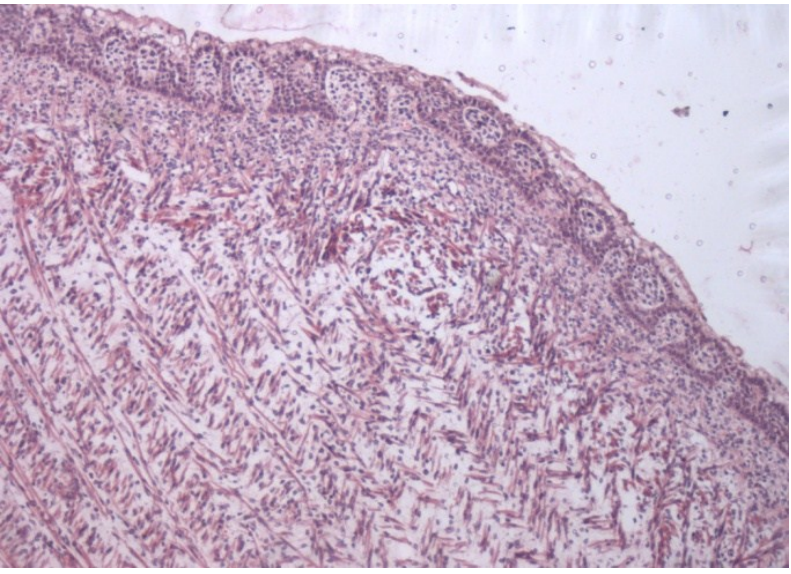

Fig. 6. Photomicrograph showing sequential evagination and invagination of the lingual epithelium on the dorsum linguae, $H \& E, 100 X$.

mous epithelium of the tongue was well developed and all the layers of the epithelium could be observed (Fig.10) and (Fig.11). Such stratification of the lingual epithelium was reported at 79-82 days of gestation or 
Yousuf Dar et al. / J. Appl. \& Nat. Sci. 9 (1): 421- 426 (2017)

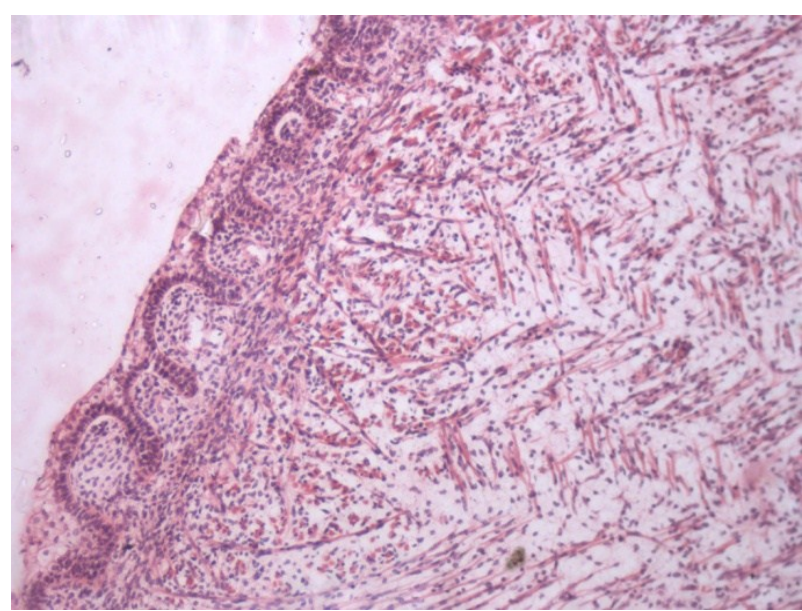

Fig. 7. Photomicrograph showing numerous growing papillae mostly fungiform appearence, $H \& E, 100 X$.

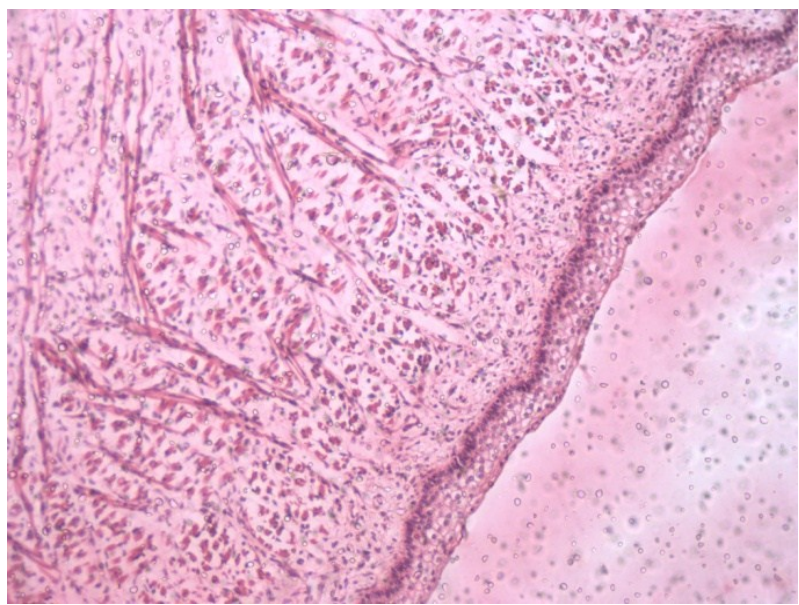

Fig. 9. Photomicrograph showing stratified squamous epithelium on the ventral surface of the tongue, $H \& E 100 X$.

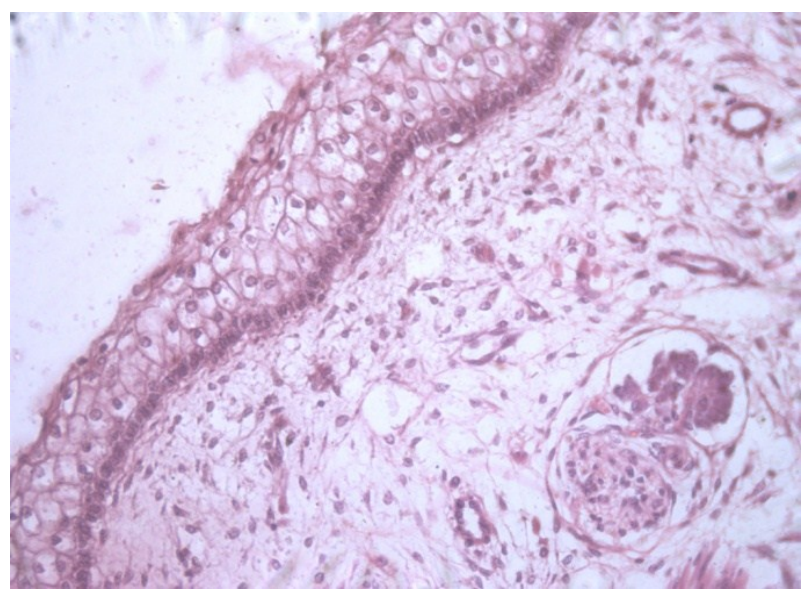

Fig.11. Photomicrograph showing stratified squamous epithelium of the tongue on ventral surface in 93 old goat foetus, $H \& E$, $200 X$.

at $30-35 \mathrm{~cm}$ CVR length in buffalo foetii (Scala et al., 2005; Uppal et al., 2006).

In this study, the first indication of presence of

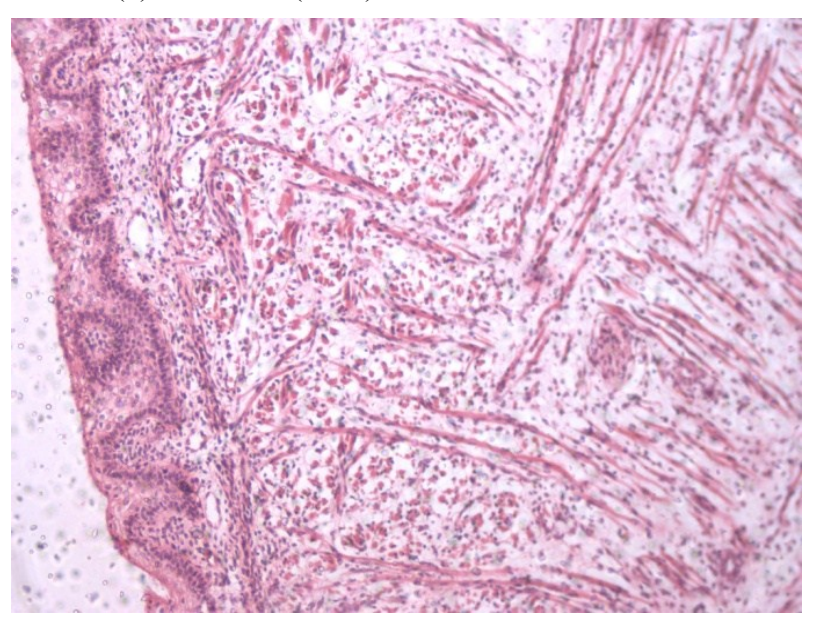

Fig. 8. Photomicrograph showing the stratified squamous epithelium of the tongue on the dorsal surface, $H \& E 100 X$.

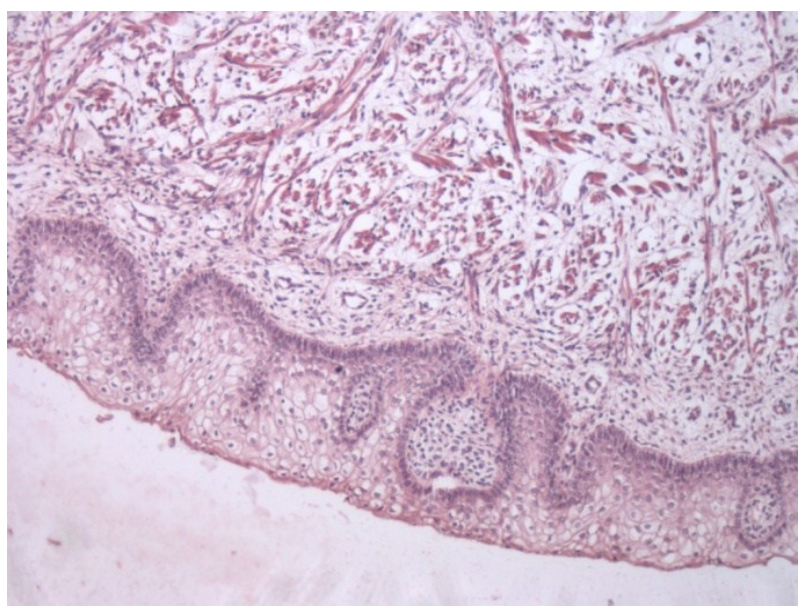

Fig. 10. Photomicrograph showing stratified squamous epithelium of tongue on the dorsal surface in 93 old goat foetus, $H \& E, 100 X$.

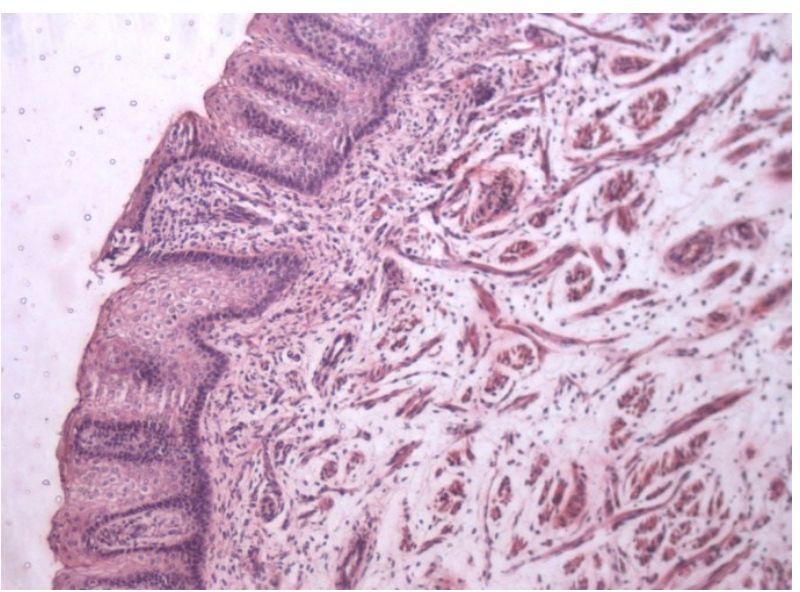

Fig. 12. Photomicrograph showing lingual stratified squamous epithelium of tongue in 120 days old goat foetus, $H \& E$, $100 X$.

keratohyaline granules was evident on the epithelium of the dorsum linguae (Fig.10) at the posterior part of the tongue at the level of torus linguae in goat foetii at 


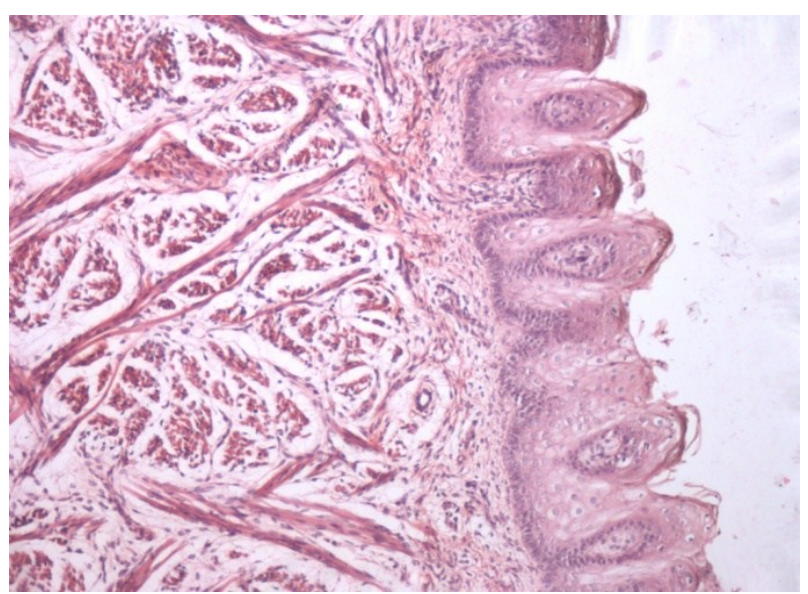

Fig. 13. Photomicrograph showing stratified squamous epithelium with keratinization in tongue of 135 days old goat foetus, $H \& E, 100 X$.

96 days of gestation $(\mathrm{CRL}=19.0 \mathrm{~cm})$. Parmar et al. (1999) also reported that keratohyaline granules in the lingual epithelium was first observed on the posterior portion of the tongue in goat foetii. These keratohyaline granules were the characteristics of the stratum granulosum or granular layer (Dellmann, 1993). In the present study it was observed that the lingual epithelium was better organized on the posterior part of the tongue as compared to the anterior aspect. Farbman (1971) emphasized that during prenatal development, the stratified squamous non keratinized lingual epithelium was formed first and gradually it was keratinized, reached the surface and sloughed off. The cells became keratinized before it reaches the surface and usually one or more layers of keratinized cells were formed beneath the superficial non keratinized cells, the cells in the intermediate layers released the keratohyaline granules and undergo keratinization as it reached the surface.

Group III: In the foetii of gestational age of 100 days onwards, the lingual epithelium became more thickened with all the typical layers of stratified squamous epithelium (Fig.12). The surface layer of the stratified epithelium of the tongue showed various degrees of keratinisation (Fig.13). The process of keratinization of the tongue has been reported during $7^{\text {th }}$ month of gestation in human foetii (Sawaf et al., 1991), while the process keratinization of lingual epithelium of rat starts just before birth (Farbman, 1971). Again, the keratinization in the lingual epithelium was observed in buffalo foetii of 30-35 cm CVR length (Scala et al., 2005). The process of keratinization started from 90 days onwards of prenatal life in Red Sokoto goat (Igbokwe and Okolie, 2009). The variation in the process of onset of keratinization of the lingual epithelium during prenatal life in different species might be due to variations in the gestation period (Iwasaki et al., 1999). During prenatal development, the stratified nonkeratinized epithelium was formed first and later on, it keratinied, but only after at least one generation of cell had matured, reached the surface and sloughed off. Similar types of findings were reported in Indian goat (Qayyum and Beg, 1975) and buffalo (Dhingra and Barnwal, 1980) and in Red Sokoto goat (Igbokwe and Okolie, 2009).

On the basis of this investigation it was interpreted that the tongue was lined by 3-4 layered epithelium in the foetus at 40 days of gestation $(C R L=2.40 \mathrm{~cm})$. At 62 days of gestation $(\mathrm{CRL}=10.10 \mathrm{~cm})$, the lamina epithelialis of the tongue of goat foetus was distinctly stratified. At $80-84$ days of gestation $(C R L=15.3$ to $16.0 \mathrm{~cm})$, the stratified squamous epithelium of the tongue was better developed both on the dorsum and ventral surfaces. In the foetii of gestational age of 100 days onwards, the lingual epithelium of the tongue showed various degrees of keratinization.

\section{Conclusion}

The histogenesis of lingual epithelium during prenatal life in goat revealed 3-4 layers of epithelial cells and with increase in gestational age, there was stratification of epithelium. In advance stages of gestation, there was an increase in the degree of keratinization. This research further implicated that the differentiation of lingual epithelium was better on posterior side as compared to anterior side at any stage of development. The decrepancy of histogenesis and keratogenesis between different species may be due to difference in the duration of the gestation period.

\section{ACKNOWLEDGEMENTS}

The authors are thankful to the Dean F.VSc \& A.H. SKUAST Jammu for providing the necessary facilities

\section{REFERENCES}

Baratz, R. S. Farbman, A. I. (1975) Morphogenesis of rat lingual filiform papillae. American J Anat., 143:283302

Bradley, R. M. (1971) Tongue topography. In: Beidler, L. M. (ed) Handbook of sensory physiology. pp 1-30. Springer -Verlag, Berlin.

Cameron, I. L.(1966) Cell proliferation, migration and specialization in the epithelium of the mouse tongue. $J$ Exp. Zoo., 163:271-84

Dellmann, D. H. (1993) Text book of Veterinary Histology, pp. $185-193,4^{\text {th }}$ Edn., Lea \& Febiger, Philadephia.

Dhingra, L. D. Barnwal, A. K. (1979) Gross anatomical studies in the tongue of Indian buffalo (Bubalus bubalis). HAU J Res., 9: 63-68

Dyce, K. M. Sack, W. O. Weinsing, C. J. G. (1996) Text Book of Veterinary Anatomy. $2^{\text {nd }}$ Edn.,W.B. Saunders Co., Philadelphia.

Farbman, A. I. (1965) Electron Microscopic study of the developing taste bud in rat fungiform papilla. Dev Bio.,50:1422-1427

Farbman, A. I. (1971) Differentiation of oral epithelium and taste bud development. J Dev Res.,50:1422-1427

Getty, R. (1975) The Anatomy of Domestic Animals. $5^{\text {th }}$ Edn., 
W.B.Saunders Co., Philadelphia, pp: 1583.

Habel, R. E. (1975) Sisson and Grossman's The Anatomy of the Domestic Animals.Vol.1. $5^{\text {th }}$ Edn.,pp. 861-915.(Ed.) Getty R. W.B Saunders Co., Philadelphia.

Igbokwe, C. O. Okolic, C. (2009) The morphological observations of some lingual papillae in the prenatal and prepuberal stages of red sokoto goats (Capra hircus). Int J Mor., 27:145-150

Iwasaki, S. Yoshizawa, H. Kawahara, I. (1999) Study by scanning electron microscopy of the morphogenesis of three types of lingual papilla in the rat. Anat Rec.,247: 528-541

Jitpukdeebodintra, S. Chai, Y. Snead, M. L. (2002) Developmental patterning of the circumvallate papilla. Int $J$ Devl Bio., 46:755-763

Kulawik, M. (2005) The development of the mucous membrane of the tongue with special emphasis on the development of fungiform papillae in the prenatal life of the rabbit. Elect J Polish Agri Univ Vet Med., 8: 4

Labh, P. N. Mitra, N. L. (1969) A comparative histological study of mammalian tongue. J Anat Soc Ind., 16:106109

Luna, L.G. (1968) Manual of Histological Staining Methods of Armed Forces Institute of Pathology, pp. $153-173,3^{\text {rd }}$ Edn. McGraw Hill Book Co., New York.

Mistretta, C. M. (1991) Developmental neurobiology of taste. In: Getchell T, Doty R Baetoshuk L, Snow J (ed) Smell and taste in health and disease. pp 35-64. Raven Press, New York.

Mistretta, C. M. Liu, H. X. (2006) Development of fungiform papillae: Patterned Lingual gustatory organs. Arch Hist Cytol.,69: 199-208

Parmar, M. L. Malik, M. R. Taluja, J. S. (1999) Morphology of tongue in goat foetuses. Indian J Ani Sci.,69:79-81
Prakash, P. Rao, G. S. (1980) Anatomical and neurohistological studies on the tongue of Indian buffalo (Bubalus bubalus). Acta Anat., 107:373-383

Qayyum, M. A. Beg, M. A. (1975) Anatomical and neurohistological observations on the tongue of Indian goat. Acta Anat., 93: 554-567

Reece, W. O. (2004) Physiology of Domestic Animals. $12^{\text {th }}$ Edn.,Williams and Wilkins, USA., pp:502.

Sawaf, M. H. Shaban, A. H. M. Pelissier, A. Forest, N. Ouhayoun, J. P. (1991) Characterization of cytokeratin pattern in the developing human tongue. Int $J$ Dev Bio., 35:91-100

Sarma, K. Goswami, R. N. Kalita, S.N. Baishya, G. Devi, J. (2003) Morphogenesis of tongue in crossbred pig fetuses. Indian J Ani Sci.,73:1020-30

Scala, G. Corona, M. Persella, A. Girolamo, P. Vittoria, A. Scala, F. Pelagalli, G. V. (2005) The innervation of the fetal buffalo tongue (Bubalus bubalis). Anat Histol Embry., 29: 203-272

Singh, Y. Sharma, D. N. Dhingra, L. D. (1979). Morphogenesis of the testis in goats. Indian J Ani Sci., 49: 925-931

Sisson, S. Grossman, J. D. (1975) The Anatomy of Domestic Mammals. $4^{\text {th }}$ Edn., W. B. Saunders Co., Philadelphia, pp: $558-563$

Uppal, V. Roy, K. S. Bansal, N. Bawa, B. S. Singh, O. (2006) Histogenesis of tongue during early prenatal life in Murrah buffalo. Indian J Ani Sci., 76:894-896.

Verma, D. Uppal, V. Bansal, N. (2010) Histogenesis of lingual epithelium during prenatal life in buffalo. Indian J Ani Sci., 80: 333-335

Yamane, A. (2005) Embryonic and postnatal development of masticatory and tongue muscles. Cell Tissue Res., 322:183-189 